\title{
硬セッコウ系プラスターを用いたポリマーセッコウモルタル の水和特性㧍よび物理的性質
}

\author{
若杉三紀夫* 山本 高 広**
}

\author{
Hydration Characteristics and Physical Properties of Polymer-Modified \\ Gypsum Mortars Using Anhydrite Plaster
}

by

\section{Mikio WAKASUGI* and Takahiro YAMAMOTo**}

\begin{abstract}
The effects of three types of polymer modification on both hydration characteristics and physical properties of the gypsum pastes and mortars originated from anhydrite plaster have been studied at various polymer-gypsum ratios. The polymer dispersions used were ethylene-vinyl acetate (EVA), polyacrylic ester and styrene-butadiene rubber. The degree of hydration of the gypsum pastes and mortars was examined by $\mathrm{X}$-ray diffraction, scanning electron microscopy, differential scanning calorimetry and porosity measurement. The setting time of fresh gypsum mortars (polymer-modified and unmodified) as well as the physical properties of hardened gypsum mortars were also measured. The hydration was complete in about 3 days, and the degree of hydration of the polymer-modified gypsum mortars was smaller than that of unmodified mortar. The setting time of gypsum mortars was retarded by the addition of polymer, and was affected by the chemical structure of polymer. The flexural and tensile strengths of the EVA-modified mortar with a polymer-gypsum ratio of $5 \%$ were higher than those of unmodified mortar. Its elastic modulus was the smallest of all, and further EVA-modified mortars showed small linear expansion. From the above test results, the EVA-modified gypsum mortar with a polymer-gypsum ratio of $5 \%$ was shown to be one of the candidates of the better plastering materials for polystyrene and polyurethane foams.
\end{abstract}

Key words : Polymer modified, Gypsum mortar, Properties and hydration, Polystyrene form, Polyurethane form, Anhydrite plaster

\section{1 はじめに}

最近の建築物には, コンクリートの内断熱材として, ポリスチレンフォームやポリウレタンフォーム等の有 機質系発泡材が用いられている. その仕上げには乾式 のセッコウボード直張り工法が一般的に採用されてい るが, 内部結露, かびの発生, 耐衝撃性および遮音性 に劣る等の欠点が指摘されている. 湿式工法で仕上げ ることができれば，上述した問題点は解決される。こ のような仕上げ用の湿式材料には, 乾燥収縮がなく, 弾性係数は低く, 曲げおよび引張強度は高いという性 質が必要とされる. 代表的な湿式材料にはセメントモ ルタル, 半水セッコウ系プラスターなどがある. しか し, セメントモルタルは乾燥収縮が大きく, 半水セッ コウ系プラスターは強度が不十分なため, ひびわれお よびはく離の危険性があり適用できない．

そこで, 適用可能な湿式材料の開発を目的として,
乾燥収縮が小さく, 強度が高いという特徽を持つ硬 セッコウ系プラスターに, 種々のポリマーディスパー ジョンを混入したポリマーセッコウペーストおよびモ ルタル（PGP および PGM : polymer-modified gypsum paste および mortar) の物性を調べた．その結果, ある種の PGM では, 前述した性質が付与されること がわかったので, 実際の工事に適用し, 追跡調査をし たところ, 施工後 $2 \sim 3$ 年を経ても, ひびわれおよび はく離の発生をみないことが確認された。

本研究では, 有機質系発泡断熱材の表面仕上げ材の 開発に当たって行った実験のうち，硬セッコウ系プラ スターを用いた PGP および PGM の水和特性および 物理的性質の測定結果について報告する. 実験に当 たって, ポリマーディスバージョンの種類掞よび混入 量を変えた PGP および PGM の供試体を作製し, 粉 末 $\mathrm{X}$ 線回折法 (XRD), 走査型電子顕微鏡 (SEM)

$\dagger \quad$ 原稿受理 平成 2 年12月 6 日 Received Dec. 6, 1990

* 正会員 大阪セメント(株)中央研究所 大阪市大正区南恩加島, Central Research Laboratory, Osaka Cement Co. Ltd., Minamiokajima, Taisho-ku, Osaka

** 大阪セメント(株)中央研究所 大阪市大正区南恩加島, Central Research Laboratory, Osaka Cement Co. Ltd., Minamiokajima, Taisho-ku, Osaka 
Table I. Chemical compositions and physical properties of II $\mathrm{CaSO}_{4}$ plaster.

\begin{tabular}{c|c|c|c|c|c|c|c|c}
\hline \multicolumn{7}{c|}{ Chemical compositions (\%) } & \multirow{2}{*}{$\begin{array}{c}\text { Specific } \\
\text { gravity }\end{array}$} & $\begin{array}{c}\text { Blaine's specific } \\
\text { surface area }\left(\mathrm{cm}^{2} / \mathrm{g}\right)\end{array}$ \\
\hline ig. loss & insol. & $\mathrm{SiO}_{2}$ & $\mathrm{Al}_{2} \mathrm{O}_{3}$ & $\mathrm{Fe}_{2} \mathrm{O}_{3}$ & $\mathrm{CaO}$ & $\mathrm{SO}_{3}$ & 2.94 & 7250 \\
\hline 2.3 & 0.2 & 6.7 & 3.0 & 0.5 & 41.6 & 43.5 & 2.94 \\
\hline
\end{tabular}

Table II. Properties of sand.

\begin{tabular}{|c|c|c|c|c|c|c|c|c|c|}
\hline \multicolumn{6}{|c|}{ Cumulative percentage passing (\%) } & \multirow{2}{*}{$\begin{array}{l}\text { Fineness } \\
\text { modulus }\end{array}$} & \multirow{2}{*}{$\begin{array}{c}\text { Water } \\
\text { adsorption } \\
(\%)\end{array}$} & \multirow{2}{*}{$\begin{array}{l}\text { Specific gravity under } \\
\text { saturated surface-dry } \\
\text { conditions }\end{array}$} & \multirow{2}{*}{$\begin{array}{c}\text { Chloride } \\
\text { content } \\
(\%)\end{array}$} \\
\hline $5 \mathrm{~mm}$ & $2.5 \mathrm{~mm}$ & $1.2 \mathrm{~mm}$ & $0.6 \mathrm{~mm}$ & $0.3 \mathrm{~mm}$ & $0.15 \mathrm{~mm}$ & & & & \\
\hline - & 100 & 92 & 63 & 21 & 3 & 2.21 & 1.40 & 2.60 & $0.001>$ \\
\hline
\end{tabular}

Table III. Properties of polymer dispersions.

\begin{tabular}{c|c|c|c|c|c|c}
\hline $\begin{array}{c}\text { Type of } \\
\text { polymer } \\
\text { dispersion }\end{array}$ & Appearance & $\begin{array}{c}\text { Total } \\
\text { solids } \\
(\%)\end{array}$ & $\begin{array}{c}\mathrm{pH} \\
\left(20^{\circ} \mathrm{C}\right)\end{array}$ & $\begin{array}{c}\text { Spesific } \\
\text { gravity } \\
\left(20^{\circ} \mathrm{C}\right)\end{array}$ & $\begin{array}{c}\text { Viscosity } \\
\left(20^{\circ} \mathrm{C}, \mathrm{cP}\right)\end{array}$ & $\begin{array}{c}\text { Minimum film forming } \\
\text { temperature }\left({ }^{\circ} \mathrm{C}\right)\end{array}$ \\
\hline EVA & Milk-white & 45.8 & 6.0 & 1.06 & 1300 & 0 \\
PAE & Milk-white & 47.6 & 9.0 & 1.07 & 8500 & 0 \\
SBR & Milk-white & 45.1 & 9.5 & 1.00 & 120 & 0 \\
\hline
\end{tabular}

観察, 元差走査熱量測定（DSC）による水和物およ びポリマーの同定を行い, 細孔径分布を測定し, 凝結 時間, 強度, 弾性係数および乾燥収縮等の物性を測定 し，ポリマーディスパージョンの種類および混入量が PGP および PGM の水和特性および物理的性質にど のように影響するかを調べ，考察を加えた。

\section{2 使用材 料}

\section{$2 \cdot 1$ 硬セッコウ系プラスター}

硬セッコウ系プラスターは, フッ酸製造時に副生す るII 型無水セッコウを主成分とし，これに高炉スラグ 微粉末, 消石疢, 硬化促進剂および増粘剤を添加して 製造される. 本試験に使用した硬セッコウ系プラス夕 一の化学成分, 比重および粉末度を Table I に示す.

\section{$2 \cdot 2$ 骨材}

本試験に使用した砂は, 愛知県瀬戸産の山砂を水洗 し，乾燥および粒度調整したもので，その粒度分布， 吸水率，比重および塩分を Table II に示す.

$2 \cdot 3$ ポリマーディスパージョン

本試験に使用したポリマーディスパージョンは，エ チレンー酢酸ビニル (EVA) 系, ポリアクリル酸エス テル（PAE）系およびスチレンーブタジエン合成ゴム (SBR) 系の 3 種類である. それらの外観, 固形分, 比重, $\mathrm{pH}$, 粘度および最低造膜温度を Table III に,

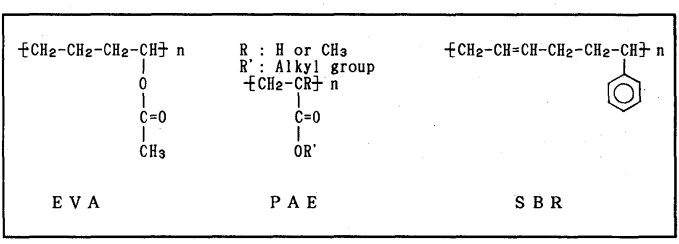

Fig. 1. Outline of chemical structures of polymer dispersions.
また，それらの主成分ポリマーの基本的な化学構造式 を Fig. 1 に示す.

\section{3 試 験 方 法}

\section{$3 \cdot 1$ 供試体の作製および養生}

供試体は, 温度 $20^{\circ} \mathrm{C}$ で, 湿度 $85 \%$ の恒温室で作 製した。所定量の水とポリマーディスパージョンを 30 秒かく拌した後，JIS R 5201 （セメントの物理試 験方法）の機械練り方法に準じて練り混ぜた.

ポリマーディスパージョンの混入量は, 硬セッコウ 系プラスターに対して, 固形分の重量比 $(P / G)$ で $0 ， 1 ， 2.5 ， 5$ および $10 \%$ とした.

ペースト供試体の場合，水は JIS R 5201 のフロー 試験でフロー值が $250 \pm 5$ となる量とした. モルタル 供試体の場合, 砂は重量比でプラスターの 2.5 倍とし, 水はフロー値で $180 \pm 2$ となる量とした. 水量はポリ マーディスパージョン中の水分と混和した水との全重 量を硬セッコウ系プラスターの重量で除して, $W / G$ で表した.

ペースト供試体は，XRD および SEM 観察に用い, モルタル供試体は, DSC, 細孔径分布, 凝結時間, 圧縮, 曲げおよび引張強度, 圧縮および曲げ弾性係数 ならびに長さ変化試験に用いた。ペーストおよびモル タル供試体の配合を Table IV に示す. 長さ変化試験 用の供試体は温度 $20^{\circ} \mathrm{C}$, 湿度 $60 \%$ の気中で, それ以 外の供試体は温度 $20^{\circ} \mathrm{C}$, 湿度 $85 \%$ の気中で養生した。

\section{$3 \cdot 2$ XRD および SEM 観察}

材令 3 日および 7 日で寸法 $4 \times 4 \times 16 \mathrm{~cm}$ のペース 卜供試体を $2 \mathrm{~mm}$ 以下の粒径に粉砕し, 多量のアセ卜 ンで洗浄後, 1 日間減圧乾燥し, 測定用試料とした。 XRD には理学電機社製の装置を用い, 測定条件は, $\mathrm{CuK} \alpha$ 線, $40 \mathrm{kV}-100 \mathrm{~mA}, 2 \theta=5 \sim 30^{\circ}$ とした. 
Table IV. Mix proportions of PGP and PGM.

\begin{tabular}{|c|c|c|c|c|}
\hline $\begin{array}{l}\text { Type of paste } \\
\text { and mortar }\end{array}$ & $P / G$ & $S / G$ & $W / G$ & Flow \\
\hline \multirow[t]{2}{*}{ Unmodified } & 0 & 0 & 0.39 & 246 \\
\hline & 0 & 2.5 & 0.44 & 181 \\
\hline \multirow[t]{5}{*}{ EVA-modified } & 0.05 & 0 & 0.38 & 247 \\
\hline & 0.01 & 2.5 & 0.45 & 182 \\
\hline & 0.025 & 2.5 & 0.46 & 182 \\
\hline & 0.05 & 2.5 & 0.47 & 181 \\
\hline & 0.10 & 2.5 & 0.49 & 178 \\
\hline \multirow[t]{5}{*}{ PAE-modified } & 0.05 & 0 & 0.43 & 248 \\
\hline & 0.01 & 2.5 & 0.44 & 180 \\
\hline & 0.025 & 2.5 & 0.45 & 181 \\
\hline & 0.05 & 2.5 & 0.46 & 182 \\
\hline & 0.10 & 2.5 & 0.48 & 180 \\
\hline \multirow[t]{5}{*}{ SBR-modified } & 0.05 & 0 & 0.23 & 251 \\
\hline & 0.01 & 2.5 & 0.44 & 181 \\
\hline & 0.025 & 2.5 & 0.45 & 179 \\
\hline & 0.05 & 2.5 & 0.45 & 180 \\
\hline & 0.10 & 2.5 & 0.48 & 179 \\
\hline
\end{tabular}

SEM 観察には日本電子社製の走查型電子顕微鏡を用 い，倍率 100 倍， 1500 倍および 3500 倍での観察を 行った.

\section{3・3 DSC および細孔径分布}

寸法 $4 \times 4 \times 16 \mathrm{~cm}$ のモルタル供試体を用いて, DSC は材令 14 日で, 細孔径分布は材令 3 日， 7 日， 14 日および 28 日で測定した，試料の調製はXRD お よび SEM 観察試料と同様に行ったＤSCにはリガ ク社製の装置を用い， $\alpha-\mathrm{Al}_{2} \mathrm{O}_{3}$ を基準物質とし, 温度 範囲を室温から $650^{\circ} \mathrm{C}$ ，昇温速度を $5{ }^{\circ} \mathrm{C} / \mathrm{min}$ とした。 細孔径分布の測定には, 細孔径 $37.5 \AA$ まで測定でき るカルボ・エルバ社製の水銀圧入式ポロシメーターを 用いた。

\section{$3 \cdot 4$ 凝結時間}

JIS A 6904 (せっこうプラスター）の凝結試験に準 じて, 温度 $20^{\circ} \mathrm{C}$, 湿度 $85 \%$ の気中でフレッシュモル タルの凝結時間を測定した.

\section{$3 \cdot 5$ 圧縮，曲げおよび引張強度}

圧縮および曲げ強度は, 寸法 $4 \times 4 \times 16 \mathrm{~cm}$ のモル タル供試体を用いて, 引張強度は寸法 $4 \times 4 \times 8 \mathrm{~cm}$ の モルタル供試体を用いて，材令 3 日， 7 日，および

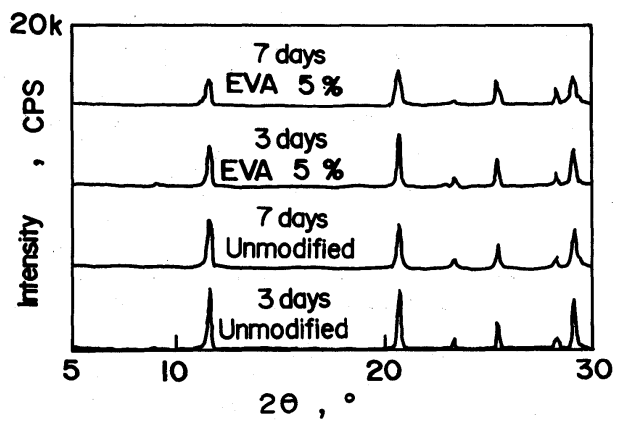

Fig. 2. XRD patterns of unmodified paste and EVA-PGP.

28 日で，島津製作所製の小容量万能試験機を用いて 測定した.

\section{$3 \cdot 6$ 圧縮および曲げ弾性係数}

ASTM C469 (Static Modulus of Elasticity and Poisson's Ratio of Concrete in Compression) に準じ て, 材令 7 日および 28 日で, 寸法 $\phi 10 \times 20 \mathrm{~cm}$ の円 柱モルタル供試体の圧縮弾性係数を測定した。また, 日本建築学会の「GRC の曲げ試験方法（案）に準じ て, 材令 7 日および 28 日で, 寸法 $25 \times 5 \times 1 \mathrm{~cm}$ のモ ルタル供試体を用いて曲げ弾性係数を測定した.

\section{$3 \cdot 7$ 長さ変化}

JIS A 1129 (セメントおよびコンクリートの長さ変 化試験方法）のコンパレーター法に準じて，寸法 4 $\times 4 \times 16 \mathrm{~cm}$ のモルタル供試体を用い, 打設後 1 日を 基長として長さ変化を測定した。

\section{4 、試験結果および考察}

\section{$4 \cdot 1$ XRD}

PGP の XRD の測定結果の一例として, 材令 3 日 および 7 日に扔ける未混入セッコウペーストと $P$ $/ G 5 \%$ の EVA 系の PGP の測定結果を Fig. 2 に示 す.また, Table V には, その粉末 $\mathrm{X}$ 線回折結果よ り二水抢よび無水セッコウのメインピーク（20 $=11.7^{\circ}$ および $25.5^{\circ}$ ）の高さ比を算出した結果を示す. これより水和反応の程度を比較すると, PGP の水和 率は，いずれも未混入セッコウペーストより小さく，

$\mathrm{PAE}$ 系 $\mathrm{PGP}<\mathrm{SBR}$ 系 $\mathrm{PGP}<\mathrm{EVA}$ 系 $\mathrm{PGP}<$ 未混入セッコウペースト

の順であった．また，材令 3 日と 7 日で水和率を比較 すると，いずれもほとんど変化していないので，七ッ

Table V. Hydrated / unhydrated gypsum ratio of PGP.

\begin{tabular}{c|c|c|c|c}
\hline \multirow{2}{*}{$\begin{array}{c}\text { Age } \\
\text { (day) }\end{array}$} & \multicolumn{4}{|c}{ Hydrated/unhydrated gypsum ratio of peak height } \\
\cline { 2 - 5 } & Unmodified & EVA-modified & PAE-modified & SBR-modified \\
\hline 3 & 2.06 & 1.32 & 0.42 & 0.76 \\
7 & 2.07 & 1.19 & 0.49 & 0.60 \\
\hline
\end{tabular}

"Notes"; Hydrated gypsum : $2 \theta=11.7^{\circ}$. Unhydrated gypsum : $2 \theta=22.5^{\circ}$. 


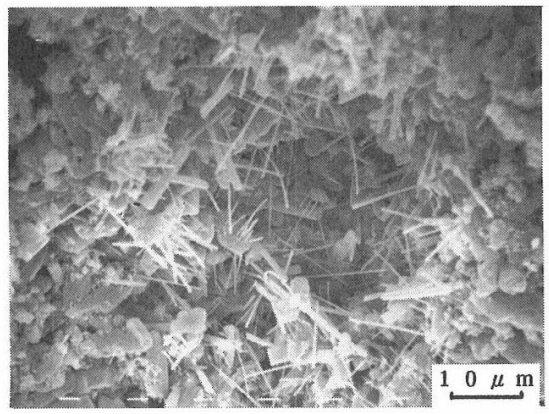

Fig. 3. SEM micrographs of unmodified paste $(\times 1500)$.

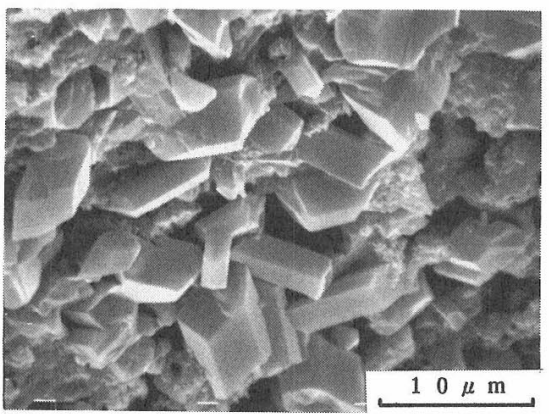

Fig. 4. SEM micrographs of EVA-PGP with $P / G$ of $5 \%(\times 3500)$.

コウの水和反応は材令 3 日でほぼ完了しているものと 考えられる.

未混入セッコウペーストおよびPGP は，いずれも 材令 3 日で $2 \theta=9.1^{\circ}$ のエトリンガイトのピークが見 られ，材令 7 日では消失しており，モノサルフェート 相に転移したものと考えられる。

\section{$4 \cdot 2$ SEM 観察}

PGP の SEM 観察結果の一例として，材令 3 日で の未混入七ッコウペーストの空げき部分の SEM 写真 をFig. 3 に，P/G 5 \% の EVA 系 PGP の空げき部分 の SEM 写真を Fig. 4 に示す. Fig. 3 の空げき部分で は硬化体に膨張性を付与するエトリンガイトの針状結 晶が見られ，Fig. 4 では角柱状の二水セッコウの結晶 と半透明質のりん片状のポリマーフィルム相が見られ た.

ポリマーディスパージョンの界面活性作用によって， PGP 中に連行された数十一数千 $\mu \mathrm{m}$ の気泡内では, 水和物の結晶がよく成長しており，気泡以外の部分と 比較して，二水セッコウやエトリンガイトの結晶が多 く存在していた。また，材令 3 日と 7 日で比較すると， 二水セッコウの量および結晶の大きさに大差はなかっ た.

\subsection{DSC}

PGM の DSC 測定結果を Fig. 5 に示す。ポリマー

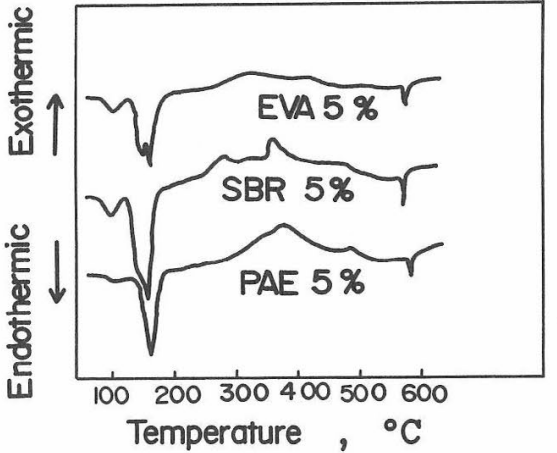

Fig. 5. DSC curves for PGM.

ディスパージョンの種類に関係なく，どの PGM も $100^{\circ} \mathrm{C} ， 150 \sim 170^{\circ} \mathrm{C}$ ，および $580^{\circ} \mathrm{C}$ に吸熱ピークがみ られた。 $100^{\circ} \mathrm{C}$ および $150 \sim 170^{\circ} \mathrm{C}$ のピークは，七ッ コウの二水塩から半水塩および半水塩から孟型無水塩 への転移反応に伴うものであり，580C のピークは骨 材の主成分である石英の相転移によるものと考えられ る.

また，200〜 500 C にかけて，ポリマーの燃焼によ るなだらかな発熱ピークが見られ，ポリマーディスパ ージョンの種類によってピークの形状が異なっていた. 既知のポリマーディスパージョンについては，ピーク の形状からある程度，種類を同定することができ，ピ ークの面積から $P / G$ を推定することができるものと 考えられる。

\section{4 細孔径分布}

未混入セッコウのモルタル拈よび $P / G 5 \%$ の EVA 系 PGM の細孔径分布の測定結果をFig. 6 に示

\section{Unmodified EVA 5\%}

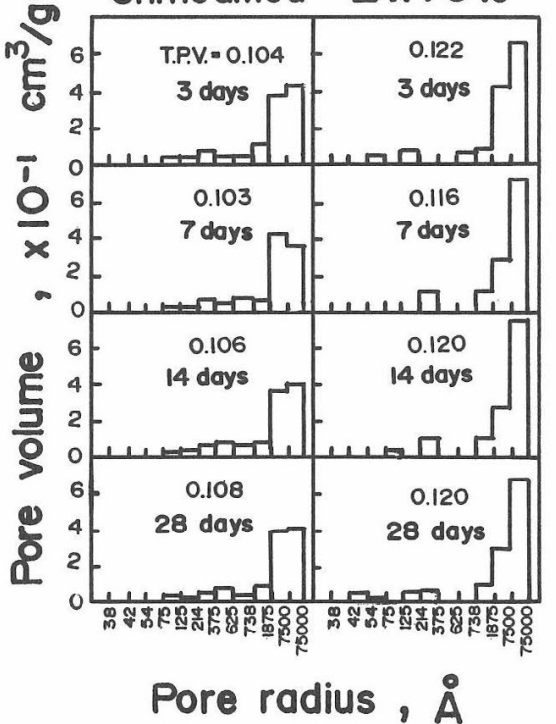

Fig. 6. Pore size distribution of unmodified mortar and EVA-PGM. 
す.いずれも 3 日以上の材令では細孔量の変化はほと んどなかったので, PGMの水和反応は 3 日でほぼ完 了しているものと考えられる. EVA 系 PGM では, 未混入セッコウモルタルと比較して, 7500 75000 A の細孔が多く，これはポリマーディスパージョンの界 面活性作用により連行された空気によるものと考えら れる. また, $738 \AA$ 以下の細孔が少なく, これはポリ マーにより充てんされたためと考えられる.

\section{$4 \cdot 5$ 凝結時間}

PGM の凝結時間は, Fig. 7 に示すように $P / G$ の

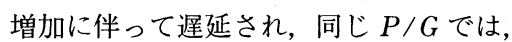

未混入セッコウモルタル $<\mathrm{SBR}$ 系 $\mathrm{PGM}<\mathrm{EVA}$

系 $\mathrm{PGM}<\mathrm{PAE}$ 系 $\mathrm{PGM}$

の順で凝結時間が長くなり，P/G5\%では，未混入 七ッコウモルタルの約 5 時間に対して, SBR 系 PGM で約 7 時間, EVA 系 PGM で約 8 時間, PAE 系 PGM で約 10 時間の終結時間であった.

これは Fig. 1 に示したように, SBR 系ポリマーが 分子構造中に酸素原子を含む官能基をほとんど持たな いのに対して, PAE 系ポリマーではアルコキシカル ボニル基（一COOR）を, EVA 系ポリマーではメト キシカルボニル基 $\left(-\mathrm{OCOCH}_{3}\right)$ を有し，これらの 官能基の遅延作用によるものと思われる。 また， $P$ $/ G$ の増加に伴って遅延されるのは, 同じフロー值に する $W / G$ が増加していることの影響も考えられる.

\section{$4 \cdot 6$ 圧縮, 曲げおよび引張強度}

$P / G 5 \%$ の PGM について, 材令と圧縮, 曲げお よび引張強度の関係をそれぞれ Fig. 8, Fig. 9 および Fig. 10 に示す. また, 材令 28 日における $P / G$ と PGM の圧縮，曲げおよび引張強度の関係をそれぞれ Fig. 11, Fig. 12 㧍よび Fig. 13 に示す.

SBR 系ポリマーディスパージョンを混入した $\beta$ 半 水セッコウモルタルの圧縮強度が未混入よりも低下す ることは既に報告されている．本研究でも，いずれの

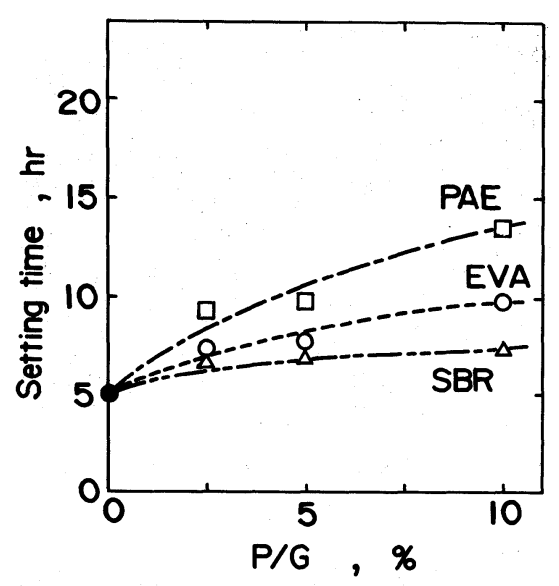

Fig. 7. Relationship between setting time and $P / G$.

ポリマーディスパージョンを用いても， $P / G$ の増加 に伴って圧縮強度は低下することが確認された．同じ $P / G$ では,

$\mathrm{PAE}$ 系 $\mathrm{PGM}=\mathrm{SBR}$ 系 $\mathrm{PGM}<\mathrm{EVA}$ 系 $\mathrm{PGM}<$

末混入セッコウモルタル

の順であった。

曲げ強度は, PAE 系および SBR 系 PGM では, $P / G$ の増加に伴って低下するのに対して, EVA 系 PGM では $P / G 5 \%$ で末混入セッコウモルタルより 大きくなる傾向がみられた.

引張強度は, $P / G 1 \%$ で,

$\mathrm{PAE}$ 系 $\mathrm{PGM}<\mathrm{SBR}$ 系 $\mathrm{PGM}<\mathrm{EVA}$ 系 $\mathrm{PGM}<$

未混入セッコウモルタル

の順で大きく, PAE 系 PGM では $1 \%$ 以上の $P / G$ でもほとんど変わらないのに対して, SBR 系および EVA 系 PGM では増加し, 特に, EVA 系 PGM では, 未混入セッコウモルタルを上回る引張強度が得られた.

EVA 系 PGM における曲げおよび引張強度の増大 は, 水和物および骨材間げきにおけるポリマー架橋構

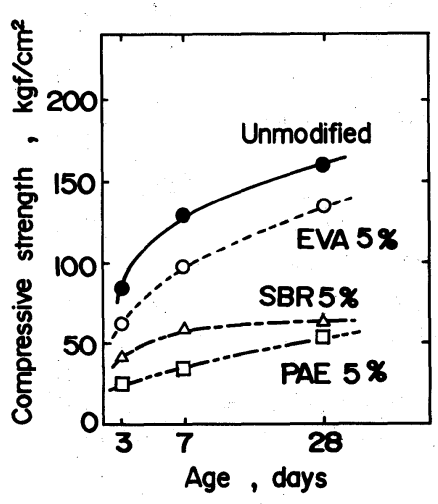

Fig. 8. Effect of type of polymer dispersion on compressive strength of PGM.

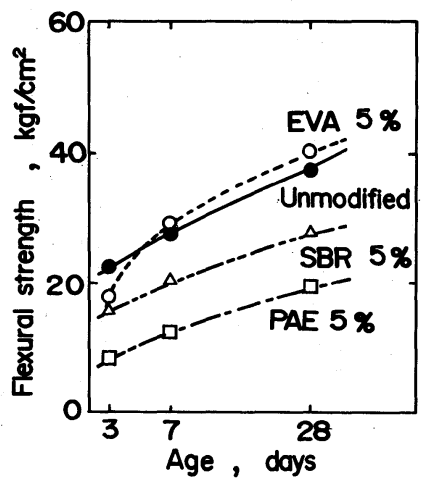

Fig. 9. Effect of type of polymer dispersion on flexural strength of PGM.

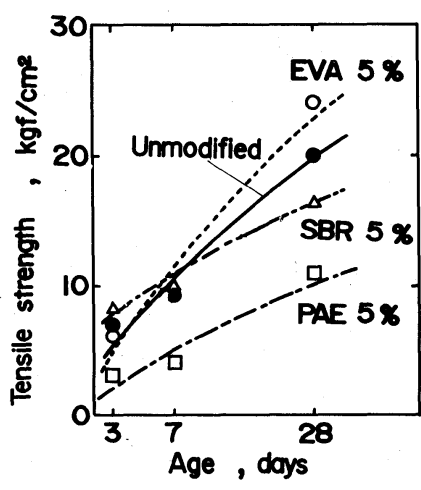

Fig. 10. Effect of type of polymer dispersion on tensile strength of PGM. 


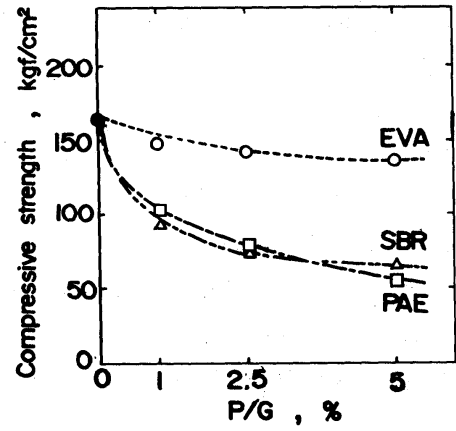

Fig. 11. Relationship between compressive strength and $P / G$

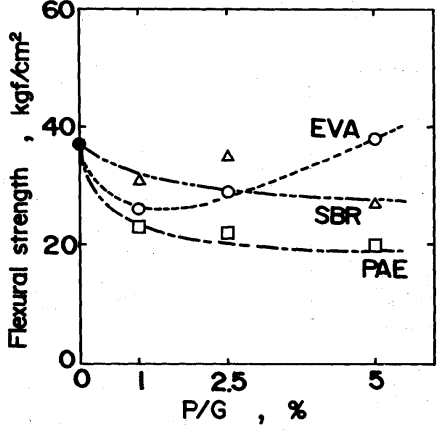

Fig. 12. Relationship between flexural strength and $P / G$.

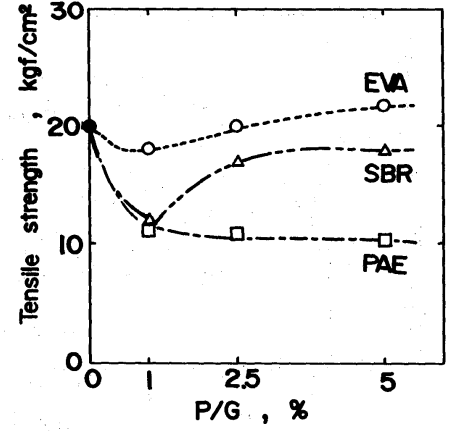

Fig. 13. Relationship between tensile strength and $P / G$.
造の形成によるものと考えられる．また，硬セッコウ 系プラスターにおけるセッコウの水和反応は前述のよ うに，材令 3 日でほぼ完了しているにもかかわらず, 強度は材令 7 日，28 日と増大している。これは，一 般的にセッコウ硬化体の細孔に存在する水分が結晶の 絡み合い抵抗を減少させ，強度を低減させるといわれ ており，したがって，乾燥に伴って細孔水が減少して 強度が増大したためと考えられる，また，高炉スラグ 微粉末の潜在水硬性による強度発現も一部影響してい るものと考えられる.

\section{$4 \cdot 7$ 弾性係数}

材令 28 日における $P / G$ と PGM の圧縮および曲 げ弾性係数の関係をそれぞれ Fig. 14 および Fig. 15 に 示す。圧縮および曲げ弾性係数は， $P / G$ の増加に 伴って低下し, 同じ $P / G$ では,

$\mathrm{EVA}$ 系 $\mathrm{PGM} \leqq \mathrm{SBR}$ 系 $\mathrm{PGM}<\mathrm{PAE}$ 系 $\mathrm{PGM}<$

未混人セッコウモルタル

の順であった.

$P / G 5 \%$ PGM に打ける圧縮弾性係数は，未 混入セッコウモルタルと比較して， EVA 系および SBR 系 PGM で約 70\%, PAE 系 PGM で約 $20 \%$ 低

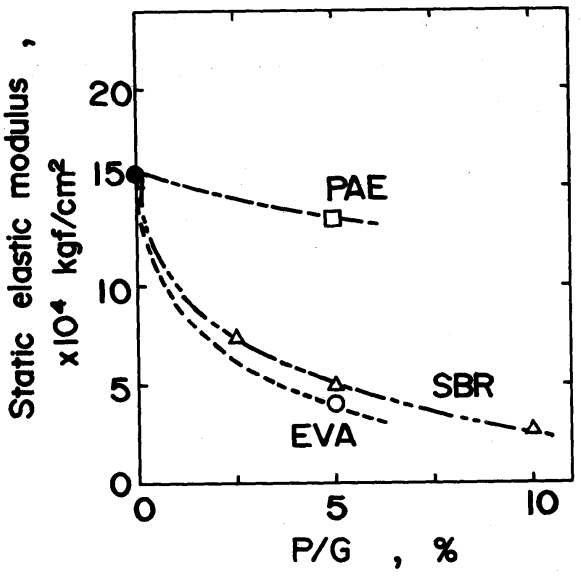

Fig. 14. Relationship between static elastic modulus and $P / G$.

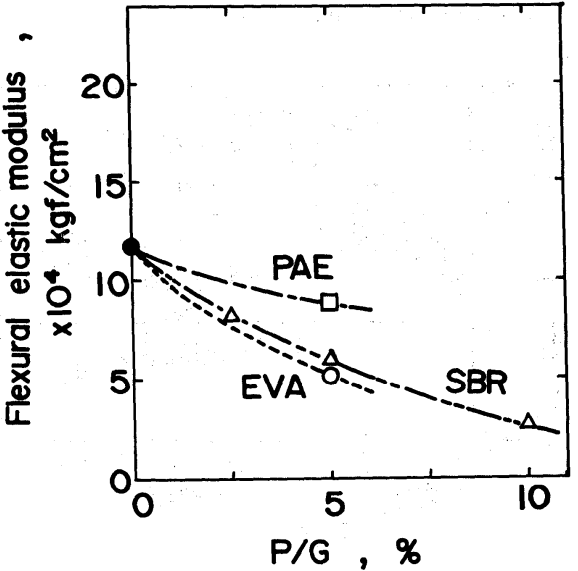

Fig. 15. Relationship between flexural elastic modulus and $P / G$.

下し，また，それらの曲げ弾性係数は，EVA 系 PGM で約 $60 \%, \mathrm{SBR}$ 系 $\mathrm{PGM}$ で約 $50 \%, \mathrm{PAE}$ 系 PGM で約 30\% 低下した.

弾性係数に関する試験結果は, 必ずしも強度試験結 果と対応するものではなかったが，一般的に，ポリマ 一セメントモルタルまたはコンクリートでもポリマー の種類および $P / G$ によって弾性係数が相当に異なり， 強度試験結果と対応しないことが報告されている.

$4 \cdot 8$ 長さ変化

$P / G 5 \%$ の PGM の長さ変化を Fig. 16 に示す. EVA 系 PGM では, 弱膨張パターンを, SBR 系 PGM では，未混入セッコウモルタルと EVA 系 PGM の中間的なパターンを，また，PAE 系 PGM では，未混入セッコウモルタルよりも早い時期に収縮 に向うパターンを示すなど, ポリマーディスパージョ ンの種類によって膨張収縮の挙動パターンが異なって いた.

弱膨張パターンをとる EVA 系 PGM でも, Fig. 17 に示すように，P/Gが $5 \%$ から $2.5 \%, 1 \%$ と少な くなるにつれて膨張も減少し，未混入セッコウモル夕 ルの挙動パターンに近づく傾向がみられた. 


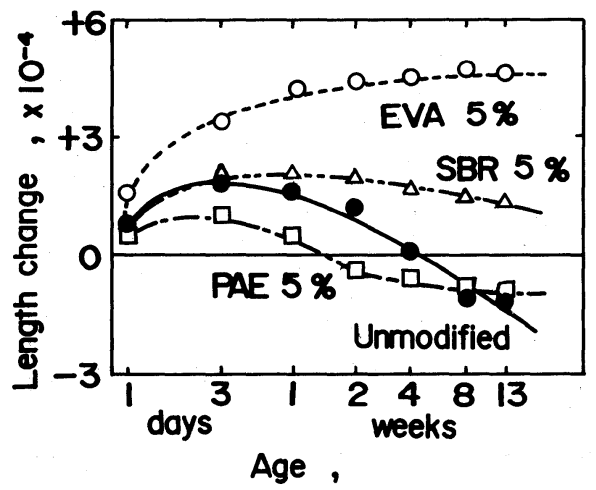

Fig. 16. Effect of type of polymer dispersion on length change of PGM.

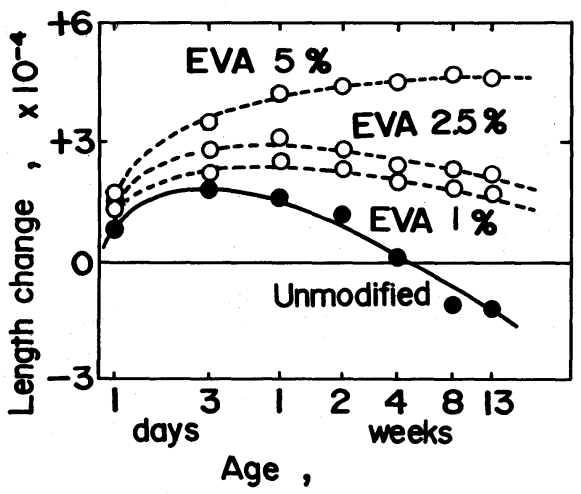

Fig. 17. Relationship between length change and $P / G$ of EVA-PGM.

本来，セッコウの水和生成物は無収縮性を示すのに 対して，未混入セッコウモルタルでは $1.8 \times 10^{-4}$ 程度 の膨張性を示した後, $-1.2 \times 10^{-4}$ 程度の収縮性を示 している. 初期の弱膨張性はセッコウと高炉スラグ微 粉末の水和反応によるエトリンガイト $\left(\mathrm{C}_{3} \mathrm{~A}\right.$ $\left.\cdot 3 \mathrm{CaSO}_{4} \cdot 32 \mathrm{H}_{2} \mathrm{O}\right)$ の生成によるものであり，その 後の収縮はエトリンガイトのモノサルフェート相 $\left(\mathrm{C}_{3} \mathrm{~A} \cdot \mathrm{CaSO}_{4} \cdot 12 \mathrm{H}_{2} \mathrm{O}\right)$ への転移および高炉スラグ 微粉末とセッコウの水和反応により生成するカルシウ ムシリケート水和物（CSH ゲル）およびカルシウム
アルミネート水和物（CAH ゲル）の収縮性の起因す るものと考えられる.

$$
5 \text { ま ぬ め }
$$

硬セッコウ系プラスターとポリマーディスパージョ ンを用いたPGMの水和反応は，ポリマーの種類およ び混入量に関係なく, 材令 3 日でほぼ完了していた。 PGMの水和率は未混入セッコウモル夕ルより小さく, またポリマーの種類によって異なり，

$\mathrm{PAE}$ 系 $\mathrm{PGM}<\mathrm{SBR}$ 系 $\mathrm{PGM}<\mathrm{EVA}$ 系 $\mathrm{PGM}<$ 末 混入セッコウモルタル

の順であったＰGM の凝結時間は $P / G$ の増加に 伴って遅れ, 遅延の程度はポリマーの種類によって異 なり，ポリマーの化学構造に影響されていた。

$P / G 5 \%$ の EVA 系 PGM の曲げおよび引張強度 は，未混入セッコウモルタルに比べて，それぞれ $10 \%$ および $20 \%$ 高く, 24 および $42 \mathrm{kgf} / \mathrm{cm}^{2}$ であっ た. その圧縮弾性係数は同じ $P / G$ で最も低く, 4 $\times 10^{4} \mathrm{kgf} / \mathrm{cm}^{2}$ であり，また EVA 系 PGM の長さ変 化は弱膨張性を示した。

これらの試験結果より，P/G5\%の EVA 系 PGM が, ポリスチレンフォームおよびポリウレタンフォー ムにより適する湿式材料の一候補であることが明らか となった.

\section{参 考 文 献}

1 ）嶋谷宏文, 四方良一, 三橋道雄, 中川民郎, 橿原義明, 大阪セメント技報，45，60（1979）。

2 ) 嶋谷宏文, 辻本 博, 若杉三紀夫, 四方田信明, 渡辺健 治，大阪セメント技報，53，29（1986）。

3 ) A. T. D. Gorton, T. D. Pendle, Rubber Development, 18, 2, 43 (1965)

4 ）山本泰彦，セメント技術年報，27，148（1973）.

5 ) 古川 宏, 日本建築学会大会学術講演梗概集 (近畿), p. 251 (1980).

6 ）関谷道去, “石高”, p. 229（1964）技報堂

7 ) 橋本 寛, 大浜嘉彦, 日本建築学会東北支部研究報告集, 31, 119 (1978). 